\title{
Maternal Monosodium Glutamate Intake Influences the Learning Ability of the Offspring of Sprague Dawley Rats
}

İlyas Ün¹, Nihal Büyükuslu²*

1 Karadeniz Technical University, Tonya Vocational School of Applied Sciences, Trabzon, Turkey.

2 Istanbul Medipol University, School of Health Sciences, Department of Nutrition and Dietetics, Istanbul, Turkey.

\section{ABSTRACT}

Objectives: Monosodium glutamate (MSG) is one of the most widely consumed food additives. We aimed to identify the effects of maternal MSG intake on offspring's learning ability in rats.

Patients and Methods: Among thirty female rats, ten control rats were fed by standart diet. Twenty rats were applied $4 \mathrm{mg} / \mathrm{g}$.body weight for 3 weeks and then divided into group I (exposed MSG during pregnancy and lactation) and group II (no MSG). Pups had no MSG at any stage. The adult rats and the pups were applied Barnes maze to test learning ability.

Results: Barnes maze test resulted that the learning ability for offspring of MSG treated mother rats decreased in the order of control > maternal MSG intake for 3 weeks before mating > additional maternal MSG intake during pregnancy and lactation.

Conclusion: In conclusion maternal MSG intake increased the duration of trial and the number of false trial of offspring in Sprague Dawley rats.

Keywords: Monosodium Glutamate, Barnes Maze, Learning Ability, Memory, Sprague Dawley Rats

\section{INTRODUCTION}

Monosodium glutamate has been using widely all around the world and contains $78 \%$ of glutamic acid, $22 \%$ of sodium and water. It is consumed as a flavor enhancer or food additive and used in many commercially packed food and cooking. ${ }^{1}$ Glutamic acid takes place in all cells of the body and acts in the intermediary metabolism and as a constituent of the proteins.

Learning is the process that modifies subsequent behavior. Memory is the ability

*Corresponding Author: Nihal Büyükuslu, email: nbuyukuslu@medipol.edu.tr (Received 09 July 2018, accepted 17 September 2018) 
to remember past experiences. The application of MSG to rats and mice during the neonatal period caused obesity, learning difficulty, gonadal dysfunction, lesions of neural structures and of the retina..$^{2-8}$ Systemic administration of MSG resulted in glutamate-induced cell death in the fetal hypothalamic neuronal cell line RCA-6 indicating the defect in specific brain regions, including hypothalamus and cerebellum. ${ }^{9}$ Indeed, neurotoxicity of MSG was found to be related with glutamate receptors activation, specifically $\mathrm{N}$-methyl D-aspartate (NMDA) receptors. ${ }^{10-13}$ Numerous studies revealed evidences that the hippocampus had a critical role in the processes related to learning and memory in human and animal subjects. ${ }^{14-16}$ Barnes maze is one of the common applied maze tests and often employed to assess learning capacity and spatial memory for mice and rats. ${ }^{17-19}$

The oral lethal dose (LD50) for MSG is $15-18 \mathrm{~g} / \mathrm{kg}$ body weight in rats and mice. ${ }^{20}$ The dose of $2 \mathrm{~g} / \mathrm{kg}$ of body weight corresponds to $140 \mathrm{~g}$ of MSG intake in a $70 \mathrm{~kg}$ man. The toxic effects on central nervous system, adipose tissue and liver, reproductive organs and other systems have been shown when the MSG intake was between $3-6 \mathrm{mg} / \mathrm{kg}$ of body weight in rats and mice. ${ }^{21-23}$ However, there is no restriction to utilize in foods and cooking as additive by the Joint FAO/ WHO Expert Committee on Food Additives (JECFA). ${ }^{24}$ It has been decades the researches have been searching the effects of MSG on many aspects of metabolism. However, the results of studies are still controversial. ${ }^{20,22}$

In the present study, we aimed to define the effects of maternal MSG intake on the learning ability and memory of offspring which had no MSG supplement.

\section{METHODOLOGY}

\section{Housing and feeding}

Experiment was conducted on 30 female Spraque Dawley rats (6-8 weeks old) and on their pups (9 weeks old). Animals were obtained from the animal house of Istanbul Medipol University. Average weight of adult rats was 163.50 $\pm 11.12 \mathrm{~g}$. The animals were housed under controlled conditions. The room temperature was $23 \pm 2^{\circ} \mathrm{C}$ and air humidity $50 \pm 5 \%$. The rhythm of light and darkness was established (light phase from 6:00 a.m. to 6:00 p.m.). The female rats were housed in standard cages. They had free access to tap water and to standard laboratory chow pellets. After the two weeks adaptation period, the animals were divided into two groups each including randomly selected rats. Control group (N=10) received standard diet all through the experimental period. The defining of the animals was succeeded via coloring their tails in different dyes during the experiment. All procedures on animals followed Guideline for work on experimental animals approved by Ethic Committee of Istanbul Medipol University. 


\section{MSG supplementation}

MSG (mw 169.11 g/mol, purity 99\%) under the license of Ajinomoto co.INC. (Tokyo, Japan) was bought in open market in Istanbul of Turkey. The solution of 30 g MSG/100 mL (1.77 M) was prepared in distilled water. The daily dose for MSG was based on the levels reported by previous studies. ${ }^{21-23}$ In the present study, the MSG supplementation (4 mg/g.bw) was applied orally by gavage. The experimental group $(\mathrm{N}=20)$ was exposed MSG in every two days till the mating period (3 weeks). Due to their sensitivity, all animals had only standard chow and water ad libitum during one week of mating period. Then, MSG supplemented 20 rats were divided into two groups. Group I $(\mathrm{N}=10)$ had no MSG and group II (N=10) supplemented with MSG during pregnancy and lactation (6 weeks); Group I and group II have been also continued to standard feeding ad libitum. MSG was exposed one in every 3 days during pregnancy and lactation. The pups had no MSG supplementation but standard diet all through the experimental period.

Breeding was succeeded with the ratio of 1 male/3 females (harem) in a large cage. Each group of pregnant rats were taken off separate cages. Pregnant females were not housed with non-pregnant/non-breeding females. One week prior to birth, females were housed in a separate cage and rat chow and tap water continuously available. Females were checked daily by a veterinary for the birth of pups. A week after birth, mothers and their pups were placed in the experimental cages. All pups were lactated. At the end of lactation period randomly selected 7 female pups per group were subjected to Barnes maze test. After completed weaning term ( 3 weeks) the mother rats and the rest of the pups were sacrificed under $100 \mu \mathrm{L} / \mathrm{kg}$ of Ketarum (1.2 mL Ketasol 100, (Graeub), o.8 mL Rompun 2\% solution, (Bayer) diluted in $8 \mathrm{~mL} \mathrm{0.9 \%} \mathrm{NaCl,} \mathrm{(Bichsel)).}$

\section{Barnes maze test}

Adult rats (11-13 weeks old, before mating) and their offspring (9 weeks old) underwent testing in the Barnes maze task to evaluate the spatial learning and memory. ${ }^{17}$ This dry-land maze consisted of a circular platform at a height of 140 $\mathrm{cm}$, with 20 holes along the perimeter. In this test, the animal was placed in the center on an open elevated platform and allowed to search for an escape box beneath one of the holes. Aversive stimuli sound ( $85 \mathrm{~dB}$ ) was used to induce searching and finding the target box. Once the animal entered the target box, the stimulus was disabled.

In pre-training trial, the rat placed in the middle of the maze under a dark colored box allowing the rat to be in random orientation before each trial. After 10 seconds loud voice, the chamber was removed off and the rat was allowed to ex- 
plore the maze. During the trials, rats from each group were randomly assigned to locate the target box. During acquisition and testing the number of false trials and the duration of trials were recorded. False trials were defined as nose pokes and head deflections over any hole that did not have the target box. The duration of trial was defined as the time it took to locate target box. The location of the goal hole was fixed across all trials and days.

Rats were trained for four trials per day with an inter-trial interval of at least 15 minutes till the average training duration reached less than 10 seconds. The number of trials, the number of false trials and the duration of trials were recorded for each rat. Following each trial, the entire maze was cleaned with $70 \%$ alcohol. A week after the group of rats reached less than 10 seconds, a probe trial was conducted to evaluate long-term memory retention without any training during the week before probe trial. Learning ability in the Barnes maze was assessed by the total numbers of false trials committed before entering the target box and the duration of trials. Memory was determined by the probe measurements. Experienced observers recorded the experimental data for each rat.

\section{Statistical analysis}

The quantitative variables were expressed as means \pm standard deviation. The values at $<10$ seconds were also given as median \pm IQR (interquartile range). All statistical analyses were performed using the SPSS statistical software (version 22.0). The study has a power of $80 \%$ involving 10 rats in each group with large effect size at the level of $5 \%$ error.

\section{RESULTS}

The Barnes maze task was applied to evaluate cognitive deficits in learning and memory of MSG exposed mother rats and their pups which had no MSG through the experimental period. The duration of trials and the number of false trials during training and probe trials were placed in Table 1. 
Table 1. Barnes maze testing results of mother rats and their offspring

\begin{tabular}{|c|c|c|c|c|c|c|c|c|c|c|c|}
\hline \multirow[b]{3}{*}{ Day } & \multirow[b]{3}{*}{$\begin{array}{l}\text { Number of } \\
\text { trials }\end{array}$} & \multicolumn{4}{|c|}{ Mother rats } & \multicolumn{6}{|c|}{ Offspring } \\
\hline & & \multicolumn{2}{|c|}{ Control group ( $\mathrm{N}=10$ ) } & \multicolumn{2}{|c|}{$\begin{array}{l}\text { MSG treated group }{ }^{\mathrm{a}} \\
(\mathrm{N}=20)\end{array}$} & \multicolumn{2}{|c|}{ Control group (N=7) } & \multicolumn{2}{|c|}{ Group $I^{b}(N=7)$} & \multicolumn{2}{|c|}{ Group $\|^{c}(\mathrm{~N}=7)$} \\
\hline & & $\begin{array}{l}\text { Duration } \\
\text { of trial } \\
\text { (second) }\end{array}$ & $\begin{array}{c}\text { Number } \\
\text { of false } \\
\text { trials }\end{array}$ & $\begin{array}{l}\text { Duration } \\
\text { of trial } \\
\text { (second) }\end{array}$ & $\begin{array}{l}\text { Number } \\
\text { of false } \\
\text { trials }\end{array}$ & $\begin{array}{l}\text { Duration } \\
\text { of trial } \\
\text { (second) }\end{array}$ & $\begin{array}{c}\text { Number } \\
\text { of false } \\
\text { trials }\end{array}$ & $\begin{array}{l}\text { Duration } \\
\text { of trial } \\
\text { (second) }\end{array}$ & $\begin{array}{c}\text { Number } \\
\text { of false } \\
\text { trials }\end{array}$ & $\begin{array}{l}\text { Duration } \\
\text { of trial } \\
\text { (second) }\end{array}$ & $\begin{array}{c}\text { Number } \\
\text { of false } \\
\text { trials }\end{array}$ \\
\hline 1 & 1 & $\begin{array}{l}77.87 \\
\pm 58.75\end{array}$ & $\begin{array}{c}5.20 \\
\pm 5.88\end{array}$ & $\begin{array}{c}83.57 \\
\pm 58.90\end{array}$ & $\begin{array}{c}6.90 \\
\pm 5.18\end{array}$ & $\begin{array}{l}128.82 \\
\pm 41.29\end{array}$ & $\begin{array}{l}11.33 \\
\pm 2.94\end{array}$ & $\begin{array}{l}136.40 \\
\pm 62.90\end{array}$ & $\begin{array}{l}11.29 \\
\pm 8.71\end{array}$ & $\begin{array}{l}139.24 \\
\pm 62.31\end{array}$ & $\begin{array}{c}9.57 \\
\pm 4.96\end{array}$ \\
\hline 2 & 5 & $\begin{array}{r}32.60 \\
\pm 16.91 \\
\end{array}$ & $\begin{array}{r}7.70 \\
\pm 4.85 \\
\end{array}$ & $\begin{array}{r}51.83 \\
\pm 49.19 \\
\end{array}$ & $\begin{array}{r}10.65 \\
\pm 11.33 \\
\end{array}$ & $\begin{array}{l}12.80 \\
\pm 8.72\end{array}$ & $\begin{array}{r}2.67 \\
\pm 3.44 \\
\end{array}$ & $\begin{array}{r}36.96 \\
\pm 23.50 \\
\end{array}$ & $\begin{array}{r}4.43 \\
\pm 1.90 \\
\end{array}$ & $\begin{array}{r}45.73 \\
\pm 53.24 \\
\end{array}$ & $\begin{array}{r}6.57 \\
\pm 5.29 \\
\end{array}$ \\
\hline & & & 2.30 & 36.40 & 7.45 & 30.57 & 8.00 & 43.55 & 9.29 & 26.03 & 5.29 \\
\hline 3 & 9 & $\begin{array}{r}17.69 \\
\pm 10.64\end{array}$ & \pm 2.31 & \pm 25.31 & \pm 5.47 & \pm 26.49 & \pm 6.16 & \pm 41.96 & \pm 7.59 & \pm 13.88 & \pm 2.06 \\
\hline 4 & 13 & $\begin{array}{l}18.77 \\
\pm 9.48\end{array}$ & $\begin{array}{r}5.10 \\
\pm 4.58\end{array}$ & $\begin{array}{r}34.40 \\
\pm 40.62\end{array}$ & $\begin{array}{l}8.35 \\
\pm 6.39\end{array}$ & $\begin{array}{r}11.24 \\
\pm 11.31\end{array}$ & $\begin{array}{l}2.67 \\
\pm 4.68\end{array}$ & $\begin{array}{r}27.32 \\
\pm 15.27\end{array}$ & $\begin{array}{r}4.57 \\
\pm 4.04\end{array}$ & $\begin{array}{r}38.41 \\
\pm 37.20\end{array}$ & $\begin{array}{r}9.00 \\
\pm 10.21\end{array}$ \\
\hline 4 & 15 & - & - & - & - & $\begin{array}{c}7.78 \\
\pm 4.22 \\
(6.64 \\
\pm 4.04) \\
\end{array}$ & $\begin{array}{r}1.50 \\
\pm 1.76 \\
(1.00 \\
\pm 1.25) \\
\end{array}$ & $\begin{array}{r}18.51 \\
\pm 13.65\end{array}$ & $\begin{array}{l}3.57 \\
\pm 3.41\end{array}$ & $\begin{array}{l}24.00 \\
\pm 17.18\end{array}$ & $\begin{array}{r}5.29 \\
\pm 3.09\end{array}$ \\
\hline 5 & 17 & $\begin{array}{c}18.14 \\
\pm 10.60\end{array}$ & $\begin{array}{r}2.90 \\
\pm 2.84\end{array}$ & $\begin{array}{r}19.91 \\
\pm 10.88 \\
\end{array}$ & $\begin{array}{r}4.90 \\
\pm 3.31\end{array}$ & - & - & $\begin{array}{r}22.66 \\
\pm 18.75 \\
\end{array}$ & $\begin{array}{r}4.86 \\
\pm 5.15\end{array}$ & $\begin{array}{r}49.14 \\
\pm 62.67 \\
\end{array}$ & $\begin{array}{r}7.29 \\
\pm 5.99\end{array}$ \\
\hline 6 & 21 & $\begin{array}{r}15.72 \\
\pm 11.61 \\
\end{array}$ & $\begin{array}{r}4.80 \\
\pm 4.80\end{array}$ & $\begin{array}{l}14.45 \\
\pm 8.08\end{array}$ & $\begin{array}{r}3.30 \\
\pm 2.70\end{array}$ & - & - & $\begin{array}{l}12.54 \\
\pm 7.36\end{array}$ & $\begin{array}{r}2.71 \\
\pm 1.98\end{array}$ & $\begin{array}{r}20.53 \\
\pm 22.55\end{array}$ & $\begin{array}{r}4.71 \\
\pm 7.97\end{array}$ \\
\hline 6 & 22 & $\begin{array}{c}9.88 \\
\pm 6.12 \\
(7.78 \\
\pm 10.70) \\
\end{array}$ & $\begin{array}{c}2.00 \\
\pm 2.49 \\
(1.00 \\
\pm 2.00) \\
\end{array}$ & $\begin{array}{l}13.22 \\
\pm 8.78\end{array}$ & $\begin{array}{r}3.60 \\
\pm 3.10\end{array}$ & - & - & - & - & - & - \\
\hline 6 & 24 & - & - & $\begin{array}{r}15.08 \\
\pm 12.69 \\
\end{array}$ & $\begin{array}{r}3.10 \\
\pm 3.83 \\
\end{array}$ & - & - & - & - & - & - \\
\hline 7 & 25 & - & - & $\begin{array}{r}14.35 \\
\pm 10.12 \\
\end{array}$ & $\begin{array}{r}4.00 \\
\pm 3.46 \\
\end{array}$ & - & - & $\begin{array}{l}10.71 \\
\pm 8.22 \\
\end{array}$ & $\begin{array}{r}2.14 \\
\pm 2.19 \\
\end{array}$ & $\begin{array}{r}21.70 \\
\pm 13.97 \\
\end{array}$ & $\begin{array}{r}4.86 \\
\pm 2.79 \\
\end{array}$ \\
\hline 7 & 27 & - & - & - & - & - & - & $\begin{array}{c}9.42 \\
\pm 6.6 \\
(7.70 \\
\pm 13.27) \\
\end{array}$ & $\begin{array}{r}2.43 \\
\pm 2.30 \\
(2.00 \\
\pm 2.00) \\
\end{array}$ & $\begin{array}{r}21.04 \\
\pm 23.42\end{array}$ & $\begin{array}{r}6.29 \\
\pm 9.59\end{array}$ \\
\hline 8 & 29 & - & - & $\begin{array}{l}18.31 \\
\pm 6.73 \\
\end{array}$ & $\begin{array}{r}5.10 \\
\pm 3.87 \\
\end{array}$ & - & - & - & - & $\begin{array}{r}24.72 \\
\pm 24.61 \\
\end{array}$ & $\begin{array}{r}5.00 \\
\pm 4.47\end{array}$ \\
\hline 8 & 32 & - & - & $\begin{array}{c}9.89 \\
\pm 5.86 \\
(7.80 \\
\pm 9.73) \\
\end{array}$ & $\begin{array}{r}1.60 \\
\pm 1.50 \\
(1.00 \\
\pm 2.75) \\
\end{array}$ & - & - & - & - & - & - \\
\hline 9 & 33 & - & - & - & - & - & - & - & - & $\begin{array}{r}16.89 \\
\pm 12.81 \\
\end{array}$ & $\begin{array}{c}4.43 \\
\pm 5.50 \\
\end{array}$ \\
\hline 9 & 34 & - & - & - & - & - & - & - & - & $\begin{array}{c}6.87 \\
\pm 2.96 \\
(8.92 \\
\pm 5.55) \\
\end{array}$ & $\begin{array}{c}1.29 \\
\pm 0.95 \\
(1.00 \\
\pm 1.00) \\
\end{array}$ \\
\hline 11 & Probe & - & - & - & - & $\begin{array}{r}11.78 \\
\pm 15.36\end{array}$ & $\begin{array}{r}3.00 \\
\pm 4.00\end{array}$ & - & - & - & - \\
\hline 13 & Probe & $\begin{array}{r}7.20 \\
\pm 5.06\end{array}$ & $\begin{array}{r}1.40 \\
\pm 2.11\end{array}$ & - & - & - & - & - & - & - & - \\
\hline 14 & Probe & - & - & - & - & - & - & $\begin{array}{r}16.67 \\
\pm 11.60 \\
\end{array}$ & $\begin{array}{r}6.71 \\
\pm 4.35 \\
\end{array}$ & - & - \\
\hline 15 & Probe & - & - & $\begin{array}{l}11.47 \\
\pm 6.45 \\
\end{array}$ & $\begin{array}{r}2.65 \\
\pm 3.17 \\
\end{array}$ & - & - & - & - & - & - \\
\hline 16 & Probe & - & - & - & - & - & - & - & - & & \\
\hline
\end{tabular}

aMother rats supplemented MSG during 3 weeks before mating and then divided into two groups. 'Group I: the offspring of MSG treated rats for 3 weeks before mating. 'Group II: the offspring of MSG treated rats for 3 weeks before mating and during pregnancy and lactation. Probe was recorded after 7 days of reaching the duration of trial time $<10$ seconds. The duration and the number of trials where the scores reached less than 10 seconds were written bold. Data were presented as mean of the group \pm standard deviation. The values at $<10$ seconds were also given as median \pm IQR (interquartile range). 
Training continued as four trials per day till the average training reached less than 10 seconds which referred the maximum learning of rats. Among four measurements the first value on each trial day was reported in the Table 1. Control group reached $>10$ seconds at the $22^{\text {nd }}$ trial $\left(6^{\text {th }}\right.$ day) whereas the rats administered MSG for 3 weeks before mating reached at the $32^{\text {nd }}$ trial ( $8^{\text {th }}$ day). On days 13 (for control group) and 15 (MSG administered group) probe trials were conducted to evaluate long-term memory retention. Control mother rats arrived to target box in 7.20 \pm 5.06 seconds with $1.40 \pm 2.11$ errors while MSG treated mother rats arrived in $11.47 \pm 6.45$ seconds with $2.65 \pm 3.17$ errors. MSG treated mother rats $(\mathrm{n}=20)$ showed weaken long-term memory compared with control rats $(\mathrm{n}=10)$. Starting from the pre-training day, control rats had shorter duration of training time for each trial day.

Additional MSG administration during pregnancy and lactation to rats (group II) affected the learning ability in their offspring more than the rats had no MSG at mentioned periods (control group and group I). The numbers of trials to reach less than 10 seconds were 34 trials for group II, 27 trials for group I and 15 trials for control group.

When the duration of trials of offspring reached less than 10 seconds the numbers of false trials for control group, group I and group II were 1.50 $\pm 1.76,2.43 \pm 2.30$ and $1.29 \pm 0.95$ respectively. Probe trials of offspring were $11.78 \pm 15.36$ seconds for control group, $16.67 \pm 11.60$ seconds for group I and 11.06 \pm 5.48 seconds for group II with the number of false trials of 3.00, 6.71 and 3.71 respectively.

The number of false trials and the duration of trials were graphed on Figure 1. The MSG treated mother rats had better Barnes maze learning in comparison with the control mother rats. The similar attitude was observed for their offspring. The duration of training of pups involved multiple daily trials spread over 4 to 9 days. The longest trial days for Barnes maze learning plotted for the pups which their mothers were exposed MSG for 3 weeks before mating and additional supplementation during pregnancy and lactation (group II). The learning ability of offspring in control group was found the lowest in comparison with the pups in other groups. 


\section{Mother}
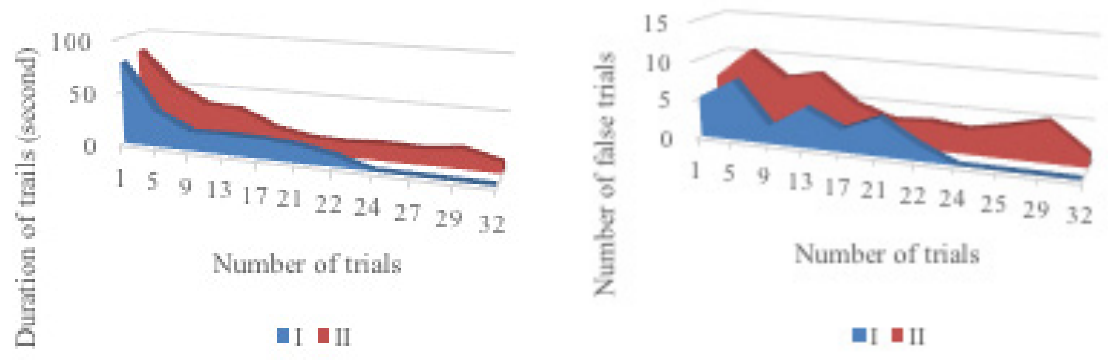

Offspring
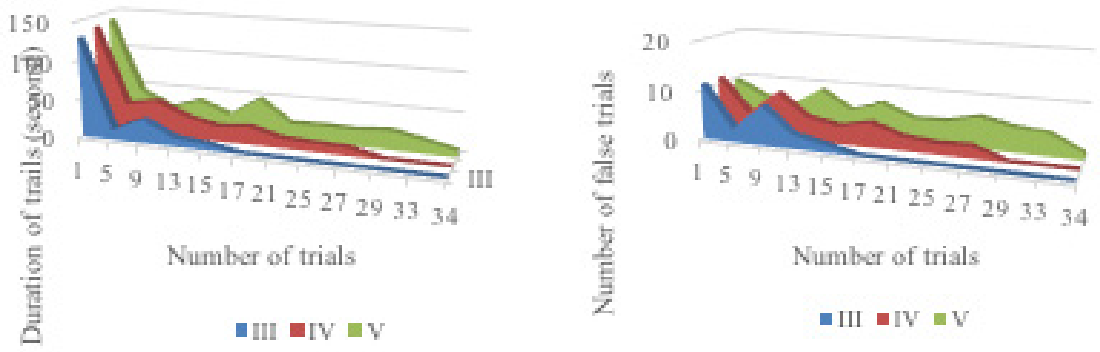

Figure 1. Number of trials vs number of false trials and duration of trials.

I: Control mother rats; II: MSG exposed mother rats for 3 weeks before mating; III: Offspring of control rats; IV: Offspring of MSG exposed mothers for 3 weeks before mating; V: Offspring of additional MSG exposed mothers during pregnancy and lactation.

\section{DISCUSSION}

Although Joint FAO/WHO Expert Committee on Food Additives (JECFA) declared no restriction to utilize MSG in foods and cooking as additive the effects of MSG intake in human and animal based studies have been evaluated for decades. $^{24}$ Moreover, toxic effects of MSG on central nervous system, adipose tissue, hepatic tissue, reproductive organs, liver and kidney functions were studied by several researchers. ${ }^{22,25-27}$ In the studies on humans, there have been many unequal experimental conditions resulting methodological limitations, such as difficulties to apply isocaloric diet, complexity of combination of diet, etc. The animal studies are preferable because of their similarity to humans and short life cycle to study whole life span or across several generations. Tough, the doses of MSG for animals are not similar that of human intake outcome of the related studies may shed some light on the effects of dietary MSG. 
In present study, MSG administered in $4 \mathrm{mg} / \mathrm{g}$.bw of adult rats for 3 weeks decreased learning ability and memory. When MSG supplementation elongated to pregnancy and lactation periods (group II), their offspring were affected more than that of control group (no MSG intake), and group I (MSG intake for 3 weeks before mating). It should be important to notice that the pups were not given MSG during experimental period. The observed effects of MSG on the learning ability and memory of offspring may arise from the maternal MSG intake. When high quantities of MSG were administered to mammals during the neonatal period it has been shown to promote a neuroendocrine dysfunction. The maternal transportation to fetal brains and kidneys following the glutamate supplementation to pregnant mice was shown by studies with radiolabeled ${ }^{3} \mathrm{H}$-glutamate. ${ }^{28}$ Thus, MSG is believed to involve the glutamate-induced degeneration of certain areas of the immature neonatal brain. However, in another study MSG was given at a late stage of pregnancy. Supporting our findings, Y-maze discrimination learning of 32- and 52 days old filial mice from mothers treated with MSG was significantly less than that of the control. ${ }^{29}$ JECFA in 2007 and 1988 defined that glutamate did not transport through fetal circulation and did not pass the placental barrier. ${ }^{24,30}$ However in a study with pregnant rhesus monkeys, it was shown that it would be necessary a very high serum maternal concentration of glutamate, of about $2.800 \mu \mathrm{mol} / \mathrm{L}$, to transfer of glutamate from the mother to the fetus to take place..$^{31}$ As a result, the JECFA allocated an "acceptable daily intake (ADI) not specified" to glutamic acid and its salts. In addition, no additional risk to infants was indicated. In a contradiction, our data indicated the slow learning ability for offspring of MSG treated rats. When we compared the learning ability and memory of pups from rats which were administered MSG before mating (group I) and plus during pregnancy and lactation (group II), the adverse effect of MSG was more in group II. The numbers of trials to drop less than 10 seconds were the highest for group II (33 trials) then for group I (27 trials) and the least for control group (15 trials) indicating the defect of maternal MSG intake on learning ability of the pups. In a same manner, the average number of false trials reached up to 1.50 (day 4) for control group, 2.43 (day 7) for group I and 4.43 (day 9) for group II. There are several studies to explore the influence of MSG directly given to adult rats or to their pups. However, our study, the first time, showed that there is an adverse effect of maternal MSG intake on learning ability of pups which did not take dietary MSG. In other words, MSG may transport from mother to fetus and cause brain damage. Leon et al. suggested that glutamate administered to pregnant rats modulates adenosine A1 receptor signaling pathways in both maternal and fetal brain, showing an adenosine A1 receptor down-regulation in fetal brain, and desensitization in maternal brain. ${ }^{32}$ 
MSG in high doses caused neuronal necrosis in hypothalamic arcuate nuclei in neonatal rats. ${ }^{33} \mathrm{MSG}$ (4 mg/g. subcutaneously on postnatal days 1, 3, 5 and 7) led to prefrontal cerebral cortex changes including fewer neurons, shorter and less ramified dendritic processes and loss of cortical cell number from postnatal day 8-14 compared to control rats. ${ }^{34,35}$ Increased proopiomelanocortin mRNA levels and adrenocorticotropic hormone concentration in the adenopituitary have been found in neonatal MSG-treated rats compared with controls (4 mg/g per bw, administrations intraperitoneally). ${ }^{36}$ Furthermore, it was shown that neonates treated with MSG exhibited neuronal cell death with reduction of photoreceptor and glial cells. ${ }^{37-39}$ Indeed, there are several studies to reveal controversial results about the effects of MSG administered in late pregnancy in animals. For instance, the effect of maternal oral administration of MSG (2.5 mg/g or 4.0 $\mathrm{mg} / \mathrm{g}$ bw) at 17-21 days of pregnancy on developing mouse fetal brain showed that there was no significant difference in spatial learning between the experimental animals and controls. However, subneurotoxic doses of MSG (2 mg/g for 10 days) given per orally to rat neonates decreased learning performance at the $90^{\text {th }}$ post-dosing day indicating the influence of early-life MSG exposure on behavioral aberrations in adulthood. $4^{\circ}$

The study has several limitations. First, the mothers and pups were not paired for the comparison of learning and memory abilities. Ten mother rats for each group were included to study. However, we randomly selected seven female pups from each group of rats. So, the mother of each pup was not definite. As a result, we could not able to detect the learning and memory behaviors of the mother and its pup as a pair. Second, the duration and the number of trials were recorded for each tested animal. However, the data evaluated through the mean values and the standard deviations of the rats in each group. When the mean of the duration of trial reached less than 10 seconds, it was accepted as the exact number of trials for learning of group. The learning and memory abilities of rats were evaluated as a group but not individually.

\section{CONCLUSION}

Barnes maze learning test revealed that the duration of trials and the number of false trials increased in MSG exposed mother rats for 3 weeks before mating. The additional intake of MSG during pregnancy and lactation influenced learning ability of pups. The learning ability of offspring was measured by the number of false trials till the average training duration less than 10 seconds. The numbers of false trials increased in the order of control group (no MSG intake), group I (maternal MSG intake for 3 weeks before mating) and group II (maternal MSG intake additionally during pregnancy and lactation). In conclusion, we hypoth- 
esized that maternal MSG intake of Spraque Dawley rats (4 mg/g.bw) affected learning ability of their offspring although the pups had no MSG during whole experimental period.

\section{CONFLICT OF INTEREST}

No conflict of interest was reported by the authors

\section{ACKNOWLEDGEMENTS}

The authors thank to the veterinary and staff of Animal House of Istanbul Medipol University.

\section{REFERENCES}

1. Samuels, A. The toxicity/safety of MSG: a study in suppression of information. Account. Res.1999, 6, 259-310.

2. von Diemen, V; Trindade, M.R. Effect of the oral administration of monosodium glutamate during pregnancy and breast-feeding in the offspring of pregnant Wistar rats. Acta. Cir. Bras. 2010, 25(1), 37-42.

3. Tsuneyama, K; Nishida, T; Baba, H; Taira, S; Fujimoto, M; Nomoto, K. Neonatal monosodium glutamate treatment causes obesity, diabetes, and macrovesicular steatohepatitis with liver nodules in DIAR mice. J. Gastroenterol. Hepatol. 2014, 29, 1736-1743.

4. Olvera-Cortes, E; Lopez-Vazquez, M.A.; Beas-Zarate, C; Gonzalez-Burgos, I. Neonatalexposuretomonosodiumglutamatedisruptsplacelearningability in adultrats. Pharmacol. Biochem. Behav. 2005, 82, 247-251.

5. Pizzi, W.J.; Barnhart, J.E.; Fanslow, D.J. Monosodium glutamate administration to the newborn reduces reproductive ability in female and male mice. Science 1978, 196, 452-454.

6. Ishikawa, M. Abnormalities in glutamate metabolism and excitotoxicity in the retinal diseases. Scientifica, 2013, http://dx.doi.org/10.1155/2013/528940.

7. Kardeşler, A.Ç.; Başkale E. Investigation of the behavioral and neurochemical effects of monosodium glutamate on neonatal rats. Turk. J. Med. Sci. 2017, 47, 1002-1011.

8. Abu-Taweel, G.M.; Zyadah, M.A.; Ajarem, J.; Ahmad, M. Cognitive and biochemical effects of monosodium glutamate and aspartame, administered individually and in combination in male albino mice. Neurotoxicol. Teratol. 2014, 42, 60-67.

9. Delgado-Rubin, A; Chowen, J.A.; Argente, J.; Frago, L.M. Growth hormone releasing peptide 6 acts as a survival factor in glutamate-induced excitotoxicity. J. Neurochem. 2006, 99, 839849 .

10. Yonden, Z.; Ozcan, O.; Gocmen, A.Y.; Delibaş, N. The effects of monosodium glutamate and aspartame on rat hippocampal N-methyl-D-aspartate receptor subunits and oxidative stress biomarkers. Int. J. Clin. Exp. Med. 2016, 9(2), 1864-1870.

11. Gao, J.; Wu, J.; Zhao, X.N.; Zhang, W.N.; Zhang, Y.Y.; Zhang, Z.X. Transplacental neurotoxic effects of monosodium brain areas of filial mice. Sheng Li Xue. Bao. 1994, 46(1), 44-51 (in Chinese).

12. Beas-Zarate, C.; Rivera-Huizar, S.V.; Martinez-Contreras, A.; Feria-Velasco, A.; Armendariz-Borunda, J. Changes in NMDA-receptor gene expression are associated with neurotoxicity 
induced neonatally by glutamate in the rat brain. Neurochem. Int. 2001, 39, 1-10.

13. Meldrum, B.S. Glutamate as a neurotransmitter in the brain: Review of physiology and pathology. J. Nutr. 2000, 130(4S Suppl), 1007S-1015S.

14. Preston, A.R.; Eichenbaum, H. Interplay of hippocampus and prefrontal cortex in memory. Curr. Biol. 2013, 23(17), R764-773.

15. Deuker, L.; Bellmund, J.L.; Schröder TN, Doeller CF. An event map of memory space in the hippocampus. Elife 2016, 5, e16534.

16. Burgess, N. The hippocampus, space, and viewpoints in episodic memory. Q. J. Exp. Psychol. A. 2002, 55(4), 1057-1080.

17. Barnes, C.A. Memory deficits associated with senescence: a neurophysiological and behavioral study in the rat. J. Comp. Physiol. Psychol. 1979, 93, 74-104.

18. Rodriguez, G.A.; Burns, M..; Weeber, E.J.; Rebeck, G.W. Young APOE4 targeted replacement mice exhibit poor spatial learning and memory, with reduced dendritic spine density in the medial entorhinal cortex. Learn. Mem. 2013, 20, 256-266.

19. Walker, J.M.; Fowler, S.W.; Miller, D.K., Sun, A.Y.; Weisman, G.A.; Wood, W.G et al., Spatial learning and memory impairment and increased locomotion in a transgenic amyloid precursor protein mouse model of Alzheimer's disease. Behav. Brain Res. 2011, 222, 169-175.

20. Walker, R.; Lupien J.R. The safety evaluation of monosodium glutamate. J. Nutr. 2ooo, 130, 1049S-1052S.

21. Mohammedsaleh, Z.M.; Abd El- Aziz, G. Histological studies of the effects of monosodium glutamate on the stomach in adult rats. J. Cytol. Histol. 2014, 5: 1102.

22. Husarova, V.; Ostatnikova, D. Monosodium glutamate toxic effects and their implications for human intake: A review. JMED Research. 2013, http://dx.doi.org/10.5171/2013.608765.

23. Hassan, Z.A.; Arafa, M.H.; Soliman, W.I.; Atteia, H.H.; Al-Saeed, H.F. The effects of monosodium glutamate on thymic and splenic immune functions and role of recovery (Biochemical and Histological study). J. Cytol. Histol. 2014, 5, 283.

24. JECFA. Evaluation of certain food additives and contaminants: 68th report of Joint FAO/ WHO Expert Committee on Food Additives (JECFA) WHO Technical Report Series. 2007, 947, 48-50. (World Health Organization, Geneva, Switzerland). [cited: $8^{\text {th }}$ Aug 2016]. Available from: http://whqlibdoc.who.int/publications/2007/9789241209472_eng.pdf.

25. Insawang, T.; Selmi, C.; Chaon, U.; Pethlert, S.; Yongvanit, P.; Areejitranusorn, P. et al., Monosodium glutamate (MSG) intake is associated with the prevalence of metabolic syndrome in a rural Thai population. Nutr. Metab. 2012, 9(1),http://dx.doi.org/10.1186/17437075-9-50.

26. Tawfik, M.S.; Al-Badr, N. Adverse effects of monosodium glutamate on liver and kidney functions in adult rats and potential protective effect of vitamins C and E. Food Nutr. Sci. 2012, $3,651-659$.

27. Singh, M. Fact or fiction? The MSG controversy. DASH, [cited: 21st Sep 2016]. Available from: http://nrs.harvard.edu/urn-3:HUL.InstRepos:8846733.

28. Yu, T.; Zhao, Y.; Shi, W.; Ma, R.; Yu, L. Effects of maternal oral administration of monosodium glutamate at a late stage of pregnancy on developing mouse fetal brain. Brain Res. 1997, 747(2), 195-206.

29. Zhang, Y.; Yu, L.; Ma, R.; Zhang, X.; Yu, T. Comparison of the effects of perinatal and neonatal administration of sodium ferulate on repair following excitotoxic neuronal damages induced 
by maternal oral administration of monosodium glutamate at a late stage of pregnancy. World J. Neurosci. 2012, 2, 159-165.

30. Joint FAO/WHO Expert Committee on Food Additives. L-glutamic acid and its ammonium, calcium, monosodium and potassium salts. In: Toxicological Evaluation of Certain Food Additives and Contaminants. New York: Cambridge University Press; 1988, pp. 97-161.

31. Stegink, L.D.; Pitkin, R.M.; Reynolds, W.A.; Filer, L.J.; Boaz, D.P.; Brummel, M.C. Placental transfer of glutamate and its metabolites in the primate. Am. J. Obstet. Gynecol. 1975, 122(1), 70-78.

32. Leon, D.; Albasanz, J.L.; Castillo, C.A.; Martin, M. Effect of glutamate intake during gestation on adenosine A1 receptor/adenylyl cyclase pathway in both maternal and fetal rat brain. $J$. Neurochem. 2008, 104, 435-445.

33. Pelaez, B.; Blazquez, J.L.; Pastor, F.E.; Sanchez, A.; Amat, P. Lectin histochemistry and ultrastructure of microglial response to monosodium glutamate-mediated neurotoxicity in the arcuate nucleus. Histol. Histopathol. 1999, 14(1), 165-174.

34. Gonzalez-Burgos, I.; Perez-Vega, M.I.; Beas-Zarate, C. Neonatal exposure to monosodiumglutamate induces cell death and dendritichypotrophy in rat prefrontocorticalpyramidal neurons. Neurosci. Lett. 2001, 297(2), 69-72.

35. Rivera-Cervantes, M.C.; Torres, J.S.; Feria-Velasco, A.; Armendariz-Borunda, J.; BeasZarate C. NMDA and AMPA receptor expression and cortical neuronal death are associated with p38 in glutamate-induced excitotoxicity in vivo. $J$. Neurosci. Res. 2004, 76(5), 678-687.

36. Skultetyova, I.; Kiss, A.; Jezova, D. Neurotoxic lesions induced by monosodium glutamate result in increased expression and decreased corticosterone clearance in rats. Neuroendocrinol. 1998, 67(6), 412-420.

37. Blanks, J.C.; Reif-Lehrer, L.; Casper D. Effects of monosodium glutamate on the isolated retina of the chick embryo as a function of age: A morphological study. Exp. Eye Res. 1981, 32(1), 105-124.

38. Regan, J.W.; Roeske, W.R.; Ruth, W.H.; Deshmukh, P.; Yamamura, H.I. Reductions in retinal gamma-aminobutyric acid (GABA) content and in [3H]flunitrazepam binding after postnatal monosodium glutamate injections in rats. J. Pharmacol. Exp. Ther. 1981, 218(3), 791-796.

39. Hyndman, A.G.; Adler, R. Analysis of glutamate uptake and monosodium glutamate toxicity in neural retina monolayer cultures. Brain Res. 1981, 254(2), 303-314.

40. Ali, M.M.; Bawari, M.; Misra, U.K.; Babu, G.N. Locomotor and learning deficits in adult rats exposed to monosodium-L glutamate during early life. Neurosci. Lett. 2000, 284(1-2), 57-6o. 